\title{
Faraday Centres appear doomed after criticism by Lords' panel
}

London. A proposal for a network of new research and training institutions linking British academic research with industry has been knocked firmly on the head by a committee of the House of Lords. The committee claims in a report published last Monday (8 February) that the case for the so-called Faraday Centres "has not been made successfully". This criticism, taken together with a lack of enthusiasm from the Department of Trade and Industry (DTI), makes it highly unlikely that the proposal will ever get off the ground.

The idea of the centres, named after the nineteenth century physicist Michael Faraday, was largely the brainchild of Sir John Fairclough, formerly science adviser to Margaret Thatcher when she was prime minister. Fairclough chaired a working group set up by the Prince of Wales that last year recommended creation of a number of such bodies, based loosely on Germany's Fraunhofer Institutes. These are free-standing organizations, initially endowed by public funds with research funds provided in roughly equal amounts by government and industry.

As the working group envisaged it, the centres would provide facilities for both basic and applied research, as well as postgraduate training. And shortly before last year's general election the government announced a $£ 2$ million pilot programme to enable five existing industrial research organizations each to take on up to 20 graduate students (see Nature 355, 757; 1992).

Although these are operating successfully, the DTI, under heavy pressure to reduce its research budget, has so far balked at making any greater commitment. Michael Heseltine, president of the Board of Trade, told a meeting of the House of Lords Select Committee on Science and Technology in December that it was "not my intention to take the initiative any further".

The select committee's report pours more cold water on the idea. It says that such centres are not necessary to give scientists experience in industrially relevant research nor for promoting technology transfer and suggests that other, existing schemes would be more cost-effective. "Although we accept that universities have an important role to play in industrial innovation, this scheme is not what is wanted," says the committee's chairman, Lord Flowers, who as chairman of the Science Research Council in the early 1970s was responsible for initiating various programmes, such as the "teaching company" schemes, for increasing collaboration between industry and academic research.

The main enthusiasts for Faraday Cen- tres, judging by witnesses who appeared before the Lords' committee, were research associations representing small and mediumsized enterprises (SMEs). These have been particularly enthusiastic about the idea that the government, through funding the cen-

\section{IMAGE UNAVAILABLE FOR COPYRIGHT REASONS}

\section{Lord Flowers says no.}

tres, would be supporting applied research not targeted on specific projects.

Reactions from other quarters ranged from the agnostic to the sceptical. Large industrial corporations, which already have large research laboratories and good contacts with university scientists, said they saw little need for a set of new institutions. And both the research councils and universities were concerned that the money would be taken out of their own budgets.

Among its counter-proposals, the Lords' committee suggests modifying the DTI's LINK scheme to enable it to support research themes, rather than just individual projects; expanding what it describes as the "very successful" teaching company scheme and setting up regional and local "technology clubs" to help SMEs gain access to various forms of technology transfer.

Fairclough, a former research director of IBM who now works in the investment section of the investment bankers N. M. Rothschild, says that he disagrees with the committee's conclusion and that government funding for facilities allowing both industrial and academic researchers to conduct research "is a fundamental requirement". However, he points out that the original proposal was made before last year's elections and before the government decided to produce a white paper (policy document) on research and innovation. "I am more concerned to see what the government does in the white paper than to stick to the recommendations that we made per se, in a very different financial environment", he says.

David Dickson

\section{French suspend child research pending review}

Paris. A French research group has suspended its study into children born by artificial insemination using anonymous donors in accordance with the recommendation of a government inquiry into the matter. But the inquiry, prompted by allegations that the research contravened laws on medical confidentiality, data protection and informed consent (see Nature 361, 102; 1993), stopped short of recommending legal proceedings against the Paris laboratory of Pierre Roubertoux, an indication that a grey region exists between the needs of the law and those of research.

The inquiry by the Commission Nationale de l'Informatique et des Libertés ruled that researchers at the Centre National de la Recherche Scientifique/University of Paris V Laboratory of Genetics, Neurogenetics and Behaviour had not broken the laws on data protection because they had indexed the computerized data from the study using codes and not names. Nevertheless, the commission recommended that the research should be suspended for six months until uncertainties with respect to medical confidentiality and informed consent are clarified.

The commission's major concern was that the researchers did not provide sufficient details of the experiment when asking the parents of the children for their consent. It recommended greater disclosure but conceded the relevance of the argument made by the researchers that full details would have "worried them [the parents] unnecessarily". The application of laws on informed consent to psychological research has been taken up by the national bioethics advisory committee, which is scheduled to give its opinion in a few months.

The inquiry judged that Sacha Geller, the operator of a sperm bank in Marseille, infringed existing laws by transmitting the names of the children to researchers. But it refrained from passing judgement on the question, pointing to a forthcoming parliamentary debate on a bioethics bill that would for the first time allow such information to be used for research purposes. With no legislation expected before the suspension expires, however, the legal status of research involving medical data remains in limbo.

Declan Butler 